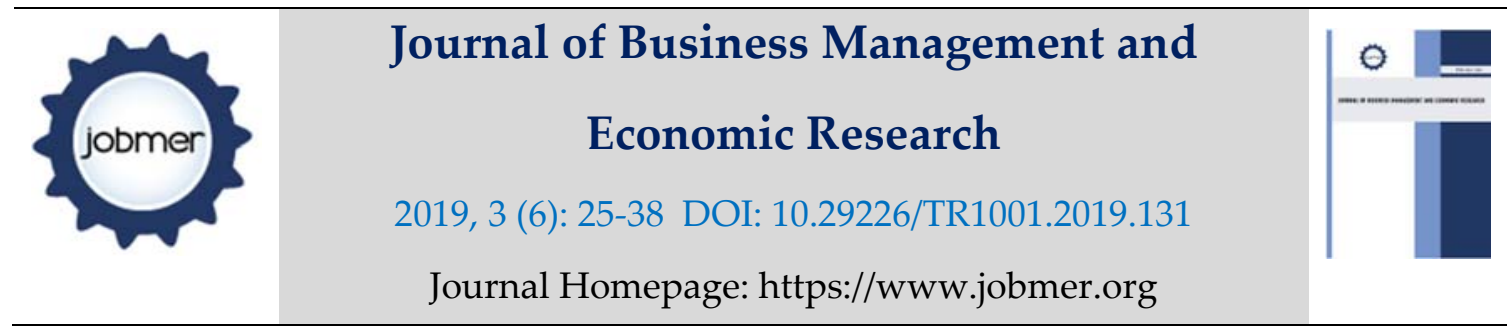

\title{
The Role of Absorptive Capacity in the Relationship Fdi and Economic Growth: A Case Study of Binh Dinh Province, Viet Nam
}

\author{
Ngo Thi Thanh Thuy \\ PhD candidate at Da Nang Economics University and lecturer at Quy Nhon University, Viet Nam \\ ngothithanhthuy@qnu.edu.vn
}

\begin{abstract}
Absorptive capacity of host countries towards foreign direct investment (FDI) has received a lot of attention from researchers around the world. However, research on this issue is still limited in Vietnam. Based on the theory of FDI absorptive capacity, this paper approaches the regression analysis method by using Autoregressive Distributed Lag model (ARDL) of Pesaran et al., 2001 to investigate and point out factors that play a role likeFDI absorptive factors with economic growth in Binh Dinh province, Vietnam. The research results shown that among the FDI absorptivefactors, the impact of FDI on economic growth in Binh Dinh province depends on human capital and local infrastructure. Thereby, this paper gives some recommendations for management agencies. Besides to focusing on FDI attraction, local authorities should pay attention to improve FDI absorptive capacity to promote the role of this capital source for economic growth.
\end{abstract}

Keywords: FDI, absorptive Capacity, economic growth, Binh Dinh - VietNam

\section{Introduction}

For host countries, FDI plays an important role in economic growth through the addition of capital, job creation, budget contributions and technology transfer promotion,...However, the benefits of FDI as well as the spillover effects from this capital do not come naturally, it needs to have a suitable environment. To acquire knowledge and take advantage of benefits from FDI, this process requires 
Journal of Business Management and Economic Research (JOBMER), vol.3, issue.6, pp.25-38

the host country to develop basic knowledge and sufficient capacity to receive the benefits provided by this capital, that is called absorptive capacity (Hoang et al., 2009). Besides, Nunnenkamp (2004) show that the host country needs to meet the initial conditions such as the basic foundation of technology and people before attracting FDI to exploit and absorb the benefits from this capital. Therefore, promoting the benefits of FDI that contribute to economic growth, besides to focusing on FDI attraction,host countries need to improve FDI absorptive capacity, this is necessary. However, during the time, the issue of attracting FDI in Vietnam in general and Binh Dinh in particular is still limited like many localitiesdid not promote the role of local factors in absorbing this capital, leading to poor FDI absorptive capacity and low disbursement rate. Hence, the objective of this study is to find empirical evidence of the role of FDI absorptive factors with local economic growth, specific case in Binh Dinh, Vietnam.

\section{Literature Review}

Previous studies have mentioned the FDI absorptive capacity on some angles. Dahlman \&Nelson (1995) have given a definetion about the FDI absorptive capacity that is the ability to learn, the ability to receive, the addition of appropriate technology and skills from developed countries. More generally, Beatrice Farkas (2012) point out that the benefits which FDI brings to the host countries are access to technology and knowledge transfer. To absorb advanced technologies, host countries need to create a convenient investment environment for the positive spread of FDI and meets some conditions for FDI absorptive capacity. These factors include quality of human resources, trade openness, quality of infrastructure and quality of institutions.

Besides to emphasizing the role of investment capital, endogenous growth theoryalso refers to the specific factors in promoting growth in the host country such as: quality of human resources, trade openness, financial market development, infrastructure system, quality of institutions and macroeconomic stability. In the relationship between FDI and economic growth, these factors have not only a direct impact but also indirect impact growth in the host country because they affect the attractive abilityand the reception of benefits from FDI. This has been confirmed in many studies (Borensztein et al., 1998; Kose et al.,2006; Cuong, 2016). It is the interaction between FDI and absorptive factors that results in growth for the local economy. 
In fact, many authors conduct empirical research to identify absorptive factors in the relationship of FDI and economic growth. They have given absorptive factors into research models to control the factors that are both absorbing factors and factors of promotion for economic growth. The research results have confirmed that the impact of FDI inflows on economic growth needs certain conditions. Typically, theresearch of Zhang (2001) for the case of China show that FDI only promotes local economic growth when localities have good infrastructure conditions, macroeconomy stability and policies to attract FDI. Another research based on the FDI absorptive capacity theory, Hoang et al. (2009) show that the host country only benefits from FDI when they meet the basic conditions related to human capital, absorptive capacity of domestic enterprises, financial systems, infrastructure and quality of institutions. With empirical evidence in research conditions in Vietnam, the authors have pointed out that there are three most important factors affecting absorptive capacity such as human capital, quality of institutions and infrastructure. Besides, Kotrajaras (2010) conducted a study of some East Asian countries, this research indicates that FDI has a positive impact on economic growth when these countries have appropriate economic conditions. These conditions include infrastructure, human capital and trade openess. In addition, Cuong (2016) shows that apsorptive capacities are also known as local factors, including economic policy issues and other features for each country such as human capital is messured by education level, quality of infrastructure and macroeconomic environment.

\section{Research Methods}

\subsection{Research site}

Binh Dinh is one of five provinces in the Central Vietnam key economic region and located in the center of the North - South axis, Vietnam. This is the locality with outstanding advantages in linking, international cooperation and economic exchange. For example, Binh Dinh is the most favorable gateway for economic activities between the Central Highlands provinces, Southern Laos, Northeast Cambodia and Thailand through Quy Nhon port and National Highway 19. In terms of geoeconomic location, Binh Dinh is a locality with enough elements in attracting investment and economic development such as: $134 \mathrm{~km}$ of coastline; Nhon Hoi economic zone, Phu Cat airport and Quy Nhon port (This is an important port of South Central Vietnam, Vietnam). In the socio-economic development goals of Binh Dinh province in particular and Vietnam in general, FDI capital is 
Journal of Business Management and Economic Research (JOBMER), vol.3, issue.6, pp.25-38

considered an engine of economic growth. However, FDI attractionand contribution of this capital source to Binh Dinh's economic growth are still limited. How to reinforce the role of FDI capital with economic growth? Solving this problem in Binh Dinh will contribute greatly in practice, and this is the reference channel for localities with similar conditions in Vietnam and around the world.

\subsection{Model}

This study provides empirical evidence about the role of FDI absorptive factors in economic growth in Binh Dinh province by developing a regression model based on research by Kotrajaras, 2010, the model is developed as follows:

$$
G_{t}=\beta_{0}+\beta_{1} F_{1} I_{t}+\sum \beta_{i} A_{i, t}+\sum \beta_{j} F_{t} I_{t} A_{j, t}+\sum \beta_{k} B_{k, t}+u_{t}
$$

The model is designed to assess the impact of FDI and absorptive factors on economic growth based on the assumption that FDI promotes economic growth through a direct channel, spillover effects and technology transfer. Besides, this study is based on the assumption that FDI promotes the benefits for economic growth depending on the initial conditions such as quality of institutions, macroeconomic stability (Kose et al., 2006). In addition, Kotrajaras (2010) concluded that infrastructure conditions, quality of human capital and trade openness help the host country better receive and absorb technology from FDI and contribute to increase total factor productivity. Therefore, there are 4 absorptive factors affecting the absorptive capacity of FDI $\left(A_{i}\right)$ which the author chose to study in accordance with local conditions including: Human capital $(\mathrm{H})$, infrastructure ( INFR), macroeconomic stability (INFL), and trade openness (OPEN).

Group of interaction variable(FDIxAt) is the product of FDI and absorptive factors (including: FDIxH; FDIxINFR; FDIxOPEN; FDIxINFL). This group is considered to represent the local FDI absorptive capacity and they are included in the model to determine the presence of absorptive factors that will increase or decrease the spread of FDI for with economic growth. To be detailed, if the interaction between FDI and human resources (FDIxH) is positive and statistically significant, it indicates that the locality has high qualified human resources, this locality will receive greater benefits from FDI in encouraging 
economic growth. Similarly, quality of infrastructure, macroeconomic stability and international trade have an interaction with FDI in promoting economic growth.

In addition, this research also use 3 control variables $\left(B_{k}\right)$. These variables are commonly used in previous studies such as capital from domestic private sector (DI), capital from state sector (GI) and labor (L). These variables are kept constant when changing the interaction and absorption variables in the regression model.

According to function 1, regression model assessing the impact of FDI on economic growth is specifically written as follows:

$$
\begin{aligned}
& \mathrm{Gt}_{\mathrm{t}}=\beta_{0}+\beta_{1} \mathrm{FDI}_{\mathrm{t}}+\beta_{2} \mathrm{DII}_{\mathrm{t}}+\beta_{3} \mathrm{GI}_{\mathrm{t}}+\beta_{4} \mathrm{~L}_{\mathrm{t}}+\beta_{5} \mathrm{H}_{\mathrm{t}}+\beta_{6} \mathrm{INFR}_{\mathrm{t}}+\beta_{7} \mathrm{OPEN}_{\mathrm{t}}+\beta_{8} \mathrm{INFL}_{\mathrm{t}}+\beta_{9} \mathrm{FDIxH}_{\mathrm{t}}+ \\
& \beta_{10} \text {FDIxINFR }_{t}+{ }^{+} \quad{ }_{11} \text { FDIxOPEN }_{t}+\beta_{12} \text { FDIxINFL }_{t}+u_{t}
\end{aligned}
$$

In which, $\mathrm{G}$ is denoted as the local economic growth rate (\%); FDI is real foreign direct investment capital (VND billion); DI is investment capital from domestic private sector in locality (billion VND); GI is public investment capital in locality (billion VND); $\mathrm{L}$ is labor (thousand people); $\mathrm{H}$ is the ratio of trained workers (\%), representing human capital; INFR is the volume of goods transported by local transport industry (thousand tons), representing infrastructure; OPEN is the total value of imports and exports, representing the openness of the economy; INFL is a consumer price index, representing the level of macroeconomic stability and Subscript $t=1997, \ldots, 2016$ represents the period 1997-2016.

\subsection{Data and analysis methods}

This research uses time series data to assess the role of absorptive factors in the relationship between FDI and economic growth in the locality, based on the application of ARDL model (Autoregressive Distributed-lagged developed by Pesaran et al., 2001). This model can overcome the disadvantages in the case of small sample sizes.

The scope of the study is limited to Binh Dinh Province, Vietnam. Secondary data from 1997-2016 was collected from the Statistical Office of Binh Dinh Province, Vietnam to serve as a basis for analysis. After collecting data, the author uses Eviews 9.0 software as a tool to assist in data analysis to perform regression estimation. When the research applies ARDL approach, the variables are converted to natural logarithms for estimation. The conversion of the original data to natural 
logarithms for the variables in the model to reduce the high dispersion as well as have some unusual observations of the original data. Thereby, the auto regressive distributed lag model - ARDL with lag (p0, p1, p2, p3, p4 ... p12) for the empirical study as follows:

$$
\begin{aligned}
& \mathrm{LG}_{\mathrm{t}}=\alpha+\sum_{i=1}^{p 0} \beta_{i 0} \mathrm{~L} G_{t-i}+\sum_{j=0}^{p 1} \beta_{j 1} \mathrm{LFDI}_{t-j}+\sum_{k=0}^{p 2} \beta_{k 2} \mathrm{~L} D I_{t-k}+\sum_{l=0}^{p 3} \beta_{l 3} \mathrm{LGI}_{t-l}+\sum_{m=0}^{p 4} \beta_{m 4} \mathrm{LL}_{t-m}+ \\
& \sum_{n=0}^{p 5} \beta_{n 5} \mathrm{LH}_{t-n^{+}} \quad \sum_{o=0}^{p 6} \beta_{o 6} \mathrm{LINFR}_{t 6-o}+\sum_{q=0}^{p 7} \beta_{q 7} \mathrm{LOPEN}_{t-q}+
\end{aligned}
$$

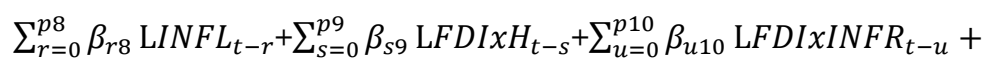

$$
\begin{aligned}
& \sum_{v=0}^{p 11} \beta_{v 11} \text { LFDIxOPEN } N_{t-v^{+}} \\
& \sum_{w=0}^{w 12} \beta_{w 12} \text { LFDIXINFL } L_{t-w}
\end{aligned}
$$

In which: $\mathrm{L} G_{t-i}, \mathrm{~L} F D I_{t-j}, \mathrm{~L} D I_{t-k}, \mathrm{~L} G I_{t-l}, \mathrm{~L} L_{t-m}, \cdots, \mathrm{L} F D I x I N F L_{t-w}$ are the stationary variables at the different lag; $\mathrm{u}_{\mathrm{t}}$ is white noise.

\section{Results and Discussion}

\subsection{Unit root tests}

In this study, the author uses Augmented Dickey-Fuller test (ADF) of the extended Dickey Fuller (1979) to check the stationary for variables in the regression model. The results of table 1 indicates that in the original string, most of the variables are not stationary at both case of having trend and no trends. Exclusively, LDI variable is a stationary string I (0) according to ADF standard with $10 \%$ significance level.When the author conducts the first difference test, most of the variables are stationary at both case of having trend and no trends with $1 \%$ significance level while LDI and LL variables are stationary strings I(1) with $10 \%$ significance level in the case of having no trend; LGI and LINEF are stationary strings I(1) with $5 \%$ and $1 \%$ significance level, respectively according to ADF standard in the case of having trend.

Table1. The result of unit root test (ADF standard)

\begin{tabular}{|c|c|c|c|c|}
\hline \multirow{2}{*}{ Variable } & \multicolumn{2}{|c|}{ Original string } & \multicolumn{2}{c|}{ First difference } \\
\cline { 2 - 5 } & No trend & Trend & No trend & Trend \\
\hline LG & -0.467570 & -1.502512 & $-9.372449^{* * *}$ & $-9.131582^{* * * *}$ \\
\hline LFDI & -0.189624 & -2.289175 & $-5.876021^{* * *}$ & $-5.602684^{* * *}$ \\
\hline LDI & 3.844322 & $-3.482453^{*}$ & $-1.608874^{*}$ & $-6.618465^{* * *}$ \\
\hline LGI & 2.129336 & -1.426668 & $-3.79247^{* * *}$ & $-4.231444^{* *}$ \\
\hline LL & 4.055455 & -2.426988 & $-1.769911^{*}$ & $-5.376118^{* * *}$ \\
\hline LH & 1.173736 & -2.564752 & $-3.818762^{* * *}$ & $-3.941088^{* *}$ \\
\hline
\end{tabular}


Journal of Business Management and Economic Research (JOBMER), vol.3, issue.6, pp.25-38

\begin{tabular}{|c|c|c|c|c|}
\hline LINFR & 3.817037 & -0.916528 & $-2.329615^{* *}$ & $-4.068162^{* *}$ \\
\hline LOPEN & 2.934824 & -2.446718 & -0.531519 & $-4.479075^{* *}$ \\
\hline LINFL & -0.038699 & -2.922999 & $-4.894014^{* * *}$ & $-4.655452^{* * *}$ \\
\hline LFDIxH & 0.008903 & -3.021289 & $-5.888478^{* * *}$ & $-5.677696^{* * *}$ \\
\hline LFDIxINFR & 0.124535 & -1.953276 & $-5.786592^{* * *}$ & $-5.639345^{* * *}$ \\
\hline LFDIxOPEN & 0.224429 & -1.880633 & $-5.921795^{* * *}$ & $-5.804162^{* * *}$ \\
\hline LFDIxINFL & 0.543046 & -2.067458 & $-5.393731^{* * *}$ & $-5.275292^{* * *}$ \\
\hline
\end{tabular}

Notes: *Significant at 10\%; **Significant at 5\%; ** Significant at 1\%

\subsection{Results estimation}

The regression results are presented in Table 2. Some variables such as Human capital $(\mathrm{H})$, infrastructure (INFR), economic openness (OPEN), macroeconomic stability (INFL), and interaction variables are in turn added from Model (1) to Model (4). Particularly in Model (5), all absorptive factors and interaction variableswith FDI are included.

Table 2. The regression results

\begin{tabular}{|c|c|c|c|c|c|}
\hline & \begin{tabular}{|c|} 
Model (1) \\
ARDL estimation \\
$(1,1,0,0,1,0,0)$ \\
(Dependent variable \\
-LG)
\end{tabular} & $\begin{array}{c}\text { Model (2) } \\
\text { ARDL estimation } \\
(1,0,1,1,0,1,0) \\
\text { (Dependent } \\
\text { variable-LG) }\end{array}$ & $\begin{array}{c}\text { Model (3) } \\
\text { ARDL estimation } \\
(1,1,1,1,1,1,1) \\
\text { (Dependent } \\
\text { variable-LG) }\end{array}$ & $\begin{array}{c}\text { Model (4) } \\
\text { ARDL estimation } \\
(1,0,1,1,1,1,1) \\
\text { (Dependent } \\
\text { variable-LG) }\end{array}$ & \begin{tabular}{|c|} 
Model (5) \\
ARDL model \\
$(1,0,0,0,0,0,0,0,0,0,0,0,0$ \\
) \\
(Dependent variable- \\
LG) \\
\end{tabular} \\
\hline LG $(-1)$ & $\begin{array}{c}0,311727 \\
(0.211528)\end{array}$ & $\begin{array}{l}-0.011098 \\
(0.023236)\end{array}$ & $\begin{array}{l}0.432155^{*} \\
(0.177844)\end{array}$ & $\begin{array}{l}-0.708233^{*} \\
(0.310473)\end{array}$ & $\begin{array}{l}-0.079418 \\
(0.111524)\end{array}$ \\
\hline LFDI & $\begin{array}{c}0.622080 \\
(0.691022)\end{array}$ & $\begin{array}{c}0.025362 \\
(0.089962)\end{array}$ & $\begin{array}{c}-0.538677^{* * *} \\
(0.110920)\end{array}$ & $\begin{array}{c}0.078605^{\text {***}} \\
(0.017104)\end{array}$ & $\begin{array}{c}0.164352 \\
(0.418250)\end{array}$ \\
\hline LFDI(-1) & $\begin{array}{c}0.096691 \\
(0.059630)\end{array}$ & - & $\begin{array}{l}-0.232727 \\
(0.158198)\end{array}$ & - & - \\
\hline LDI & $\begin{array}{c}0.689158^{* * *} \\
(0.211052)\end{array}$ & $\begin{array}{l}-0.211557 \\
(0.125062)\end{array}$ & $\begin{array}{l}0.467873^{* *} \\
(0.170062)\end{array}$ & $\begin{array}{c}0.022728 \\
(0.017148)\end{array}$ & $\begin{array}{c}0.633704^{* * *} \\
(0.081079)\end{array}$ \\
\hline LDI (-1) & - & $\begin{array}{l}0.262227^{*} \\
(0.115457)\end{array}$ & $\begin{array}{l}-0.327582 \\
(0.173356)\end{array}$ & $\begin{array}{l}0.036016^{*} \\
(0.018492)\end{array}$ & - \\
\hline LGI & $\begin{array}{c}-0.435150 \\
(0.665281)\end{array}$ & $\begin{array}{c}0.422875^{* * *} \\
(0.090946)\end{array}$ & $\begin{array}{c}1.261382^{* * *} \\
(0.249575)\end{array}$ & $\begin{array}{l}0.552325^{* *} \\
(0.175535)\end{array}$ & $\begin{array}{c}0.935614^{* * *} \\
(0.198706)\end{array}$ \\
\hline LGI(-1) & - & $\begin{array}{l}-0.221573^{*} \\
(0.090946)\end{array}$ & $\begin{array}{c}0.619868 \\
(0.378278)\end{array}$ & $\begin{array}{l}-0.235680^{*} \\
(0.109144)\end{array}$ & - \\
\hline LL & $\begin{array}{c}0.164811 \\
(0.245673)\end{array}$ & $\begin{array}{c}-0.118053 \\
(1.266880)\end{array}$ & $\begin{array}{l}-0.154076 \\
(2.549148)\end{array}$ & $\begin{array}{c}0.121181^{\text {*** }} \\
(0.005796)\end{array}$ & $\begin{array}{c}-0.110434 \\
(0.093144)\end{array}$ \\
\hline LL(-1) & $\begin{array}{c}0.156027 \\
(0.147617)\end{array}$ & - & $\begin{array}{l}-0.725688^{*} \\
(2.528525)\end{array}$ & $\begin{array}{l}0.078334^{*} \\
(0.036485)\end{array}$ & - \\
\hline
\end{tabular}




\begin{tabular}{|c|c|c|c|c|c|}
\hline C & $\begin{array}{l}11.78797^{*} \\
(5.936268)\end{array}$ & $\begin{array}{c}1.778627 \\
(3.286825)\end{array}$ & $\begin{array}{c}12.88221 \\
(9.684637) \\
\end{array}$ & $\begin{array}{l}-3.219041^{* *} \\
(1.098226)\end{array}$ & $\begin{array}{l}5.343555^{*} \\
(3.419021) \\
\end{array}$ \\
\hline \multicolumn{6}{|c|}{ Human capital variables } \\
\hline $\mathrm{LH}$ & $\begin{array}{l}1.921998^{* * *} \\
(1.270660)\end{array}$ & - & - & - & $\begin{array}{l}1.390060^{* *} \\
(0.465909)\end{array}$ \\
\hline LFDIxH & $\begin{array}{l}-0.444520^{* *} \\
(2.211510)\end{array}$ & - & - & - & $\begin{array}{l}-0.918053^{*} \\
(0.778598)\end{array}$ \\
\hline \multicolumn{6}{|c|}{ Infrastructurevariables } \\
\hline LINFR & - & $\begin{array}{c}0.440844^{* * * *} \\
(0.131010) \\
\end{array}$ & & - & $\begin{array}{l}0.923030^{*} \\
(0.366182) \\
\end{array}$ \\
\hline LINFR(-1) & - & $\begin{array}{l}-0.223183 \\
(0.182354) \\
\end{array}$ & & - & - \\
\hline LFDIxINFR & - & $\begin{array}{l}0.290724^{* * *} \\
(0.006066)\end{array}$ & & - & $\begin{array}{r}0.261498^{*} \\
(1.096472)\end{array}$ \\
\hline \multicolumn{6}{|c|}{ Trade openess variables } \\
\hline LOPEN & - & - & $\begin{array}{l}0.846334^{* *} \\
(0.266712) \\
\end{array}$ & - & $\begin{array}{c}0.160957 \\
(0.088023) \\
\end{array}$ \\
\hline LOPEN(-1) & - & - & $\begin{array}{l}1.509554^{* * *} \\
(0.327586)\end{array}$ & - & - \\
\hline LFDIXOPEN & - & - & $\begin{array}{l}-0.128856 \\
(0.195860) \\
\end{array}$ & - & $\begin{array}{l}-0.682616 \\
(1.554091) \\
\end{array}$ \\
\hline $\begin{array}{l}\text { LFDIxOPEN } \\
(-1)\end{array}$ & - & - & $\begin{array}{l}-0.137436 \\
(0.168348) \\
\end{array}$ & - & - \\
\hline \multicolumn{6}{|c|}{ Macroeconomic stability variables } \\
\hline LINFL & - & - & - & $\begin{array}{l}-0.073559^{*} \\
(0.031650) \\
\end{array}$ & $\begin{array}{l}-0.087031^{*} \\
(0.422892) \\
\end{array}$ \\
\hline LINFL(-1) & - & - & - & $\begin{array}{c}0.052782 \\
(0.032140) \\
\end{array}$ & - \\
\hline LFDIxINFL & - & & - & $\begin{array}{l}-0.784058 \\
(0.493691) \\
\end{array}$ & $\begin{array}{c}0.100147 \\
(0.092040)\end{array}$ \\
\hline $\begin{array}{l}\text { LFDIXINFL( } \\
-1)\end{array}$ & - & - & - & $\begin{array}{l}1.845829^{* *} \\
(0.565592) \\
\end{array}$ & - \\
\hline $\begin{array}{l}\text { F-Statistic; } \\
\text { Prob } \\
\end{array}$ & $\begin{array}{l}81.56808 ; \\
0.000000\end{array}$ & $\begin{array}{l}661.6483 ; \\
0.000000 \\
\end{array}$ & $\begin{array}{l}192.9508 ; \\
0.000007\end{array}$ & $\begin{array}{c}246.9741 ; \\
0.000000\end{array}$ & $\begin{array}{l}544.2727 \\
0.000001 \\
\end{array}$ \\
\hline $\begin{array}{c}\text { Autocorrelat } \\
\text { ion (LM) }\end{array}$ & $\begin{array}{c}\text { Giá trị thống kê } \chi 2 \\
=0.240375 ; \\
\text { Prob. }=0.6239\end{array}$ & $\begin{array}{c}\text { Giá trị thống kê } \chi 2 \\
=2.228404 ; \\
\text { Prob. }=0.1355\end{array}$ & $\begin{array}{c}\text { Giá trị thống kê } \chi 2 \\
=4.438527 ; \\
\text { Prob. }=0.0351\end{array}$ & $\begin{array}{c}\text { Giá trị thống kê } \chi 2 \\
=0.139929 ; \\
\text { Prob. }=0.7084\end{array}$ & $\begin{array}{c}\text { Giá trị thống kê } \chi 2 \\
=2.270969 ; \\
\text { Prob. }=0.1318\end{array}$ \\
\hline $\begin{array}{l}\text { Heteroskeda } \\
\text { sticity }\end{array}$ & $\begin{array}{c}\text { Giá trị thống kê } \chi 2 \\
=10.91626 ; \\
\text { Prob. }=0.2815\end{array}$ & $\begin{array}{c}\text { Giá trị thống kê } \chi 2 \\
=8.729152 ; \\
\text { Prob. }=0.5580\end{array}$ & $\begin{array}{c}\text { Giá trị thống kê } \chi 2 \\
=16.27472 ; \\
\text { Prob. }=0.2346\end{array}$ & $\begin{array}{c}\text { Giá trị thống kê } \chi 2 \\
=9.546648 ; \\
\text { Prob. }=0.6557\end{array}$ & $\begin{array}{c}\text { Giá trị thống kê } \chi 2 \\
=10.75112 ; \\
\text { Prob. }=0.6317\end{array}$ \\
\hline $\begin{array}{l}\text { Correct } \\
\text { function }\end{array}$ & $\begin{array}{c}\text { Giá trị thống kê F } \\
=0.042191 ;\end{array}$ & $\begin{array}{c}\text { Giá trị thống kê F } \\
=11.70562 ;\end{array}$ & $\begin{array}{c}\text { Giá trị thống kê F } \\
=0.029012 ;\end{array}$ & $\begin{array}{c}\text { Giá trị thống kê } \mathrm{F} \\
=9.813815 ;\end{array}$ & $\begin{array}{l}\text { Giá trị thống kê F } \\
=0.046505 ;\end{array}$ \\
\hline
\end{tabular}




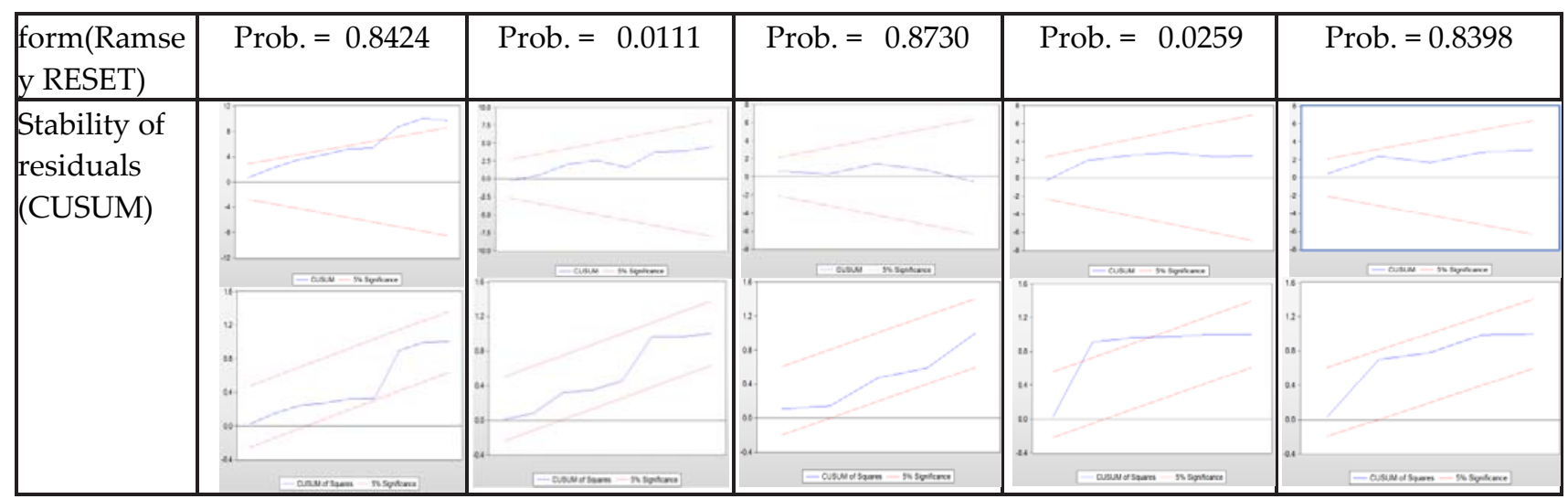

Notes: *Significant at 10\%; **Significant at 5\%; **Significant at $1 \%$. The value in () is the standard

deviation value

Based on AIC and SBC criterias, ARDL $(1,1,0,0,1,0,0)$ model with model 1, ARDL $(1,0,1,1,0,1,0)$ model with model 2, ARDL $(1,1,1,1,1,1,1)$ model with model 3, ARDL $(1,0,1,1,1,1,1)$ model with model 4 is chose. The F-statistics with P.value have a 1\% significance level that indicate the appropriate model. However, test results are performed with the stability of residuals in the model through CUSUM test - Cumulative Sum of residuals (Brown et al., 1975). The results of model 1 and model 4 are not reliable enough to estimate the short-term and long-term coefficients due to the solid line overcome the limit of two dash straight lines (this mean that cumulative sum of residuals is outside the standard range) at 10\% significance level. Besides, the results obtained by Ramsey Reset tests indicate that model 2 and model 4 omitted the variable with P. values $=0.0111$ and P.values $=0.0259$ respectively, less than 0.05. At the same time, testing for autocorrelation (Autocorrelation LM Test) in model 3 show that P.Value $=0.0351$ less than 0.05 . These show that the regression coefficients in model 1, 2, 3 and 4 models are not reliable.

Model 5 represents ARDL model $(1,0,0,0,0,0,0,0,0,0,0,0,0)$, this model includes all the adsorptive factors and intraction variables. Based on the results of the autocorrelation test, heteroskedasticity, the stability of residuals, the Model 5 is the most suitable and reliable and has no defects. CUSUM test- Cumulative Sum of residuals about autocorrelation (LM) shows P.Value = 0.1318; heteroskedasticity test shows P.Value $=0.6317$ and Ramsey RESET shows P.Value $=0,8398$. Therefore, these greater than 0.05 , showing that the model ensures reliability. 
After that, the author continues to estimate the ARDL $(1,0,0,0,0,0,0,0,0,0,0,0,0)$ model in order to determine the impact of FDI and absorptive factors on short-term and long-term economic growth through the results of table 3 as follows:

Table 3. The estimation resultsofthe impact of FDI, absorptive factors on short-term and longterm economic growth

(This case has all absorptive factors and interaction variables)

\begin{tabular}{|c|c|c|c|}
\hline \multicolumn{2}{|c|}{$\begin{array}{c}\text { Model (6) Long-term coefficient of ARDL } \\
(1,0,0,0,0,0,0,0,0,0,0,0,0) \\
\text { (Dependent variable LG) }\end{array}$} & \multicolumn{2}{|c|}{$\begin{array}{l}\text { Model (7) Short-term coefficient of ECM model based } \\
\text { onARDL approach } \\
\text { (Dependent variable } \Delta \mathrm{LG} \text { ) }\end{array}$} \\
\hline Variables & $\begin{array}{l}\text { Coefficient và T- } \\
\text { Statistics }\end{array}$ & Variables & Coefficient và T-Statistics \\
\hline LFDI & $\begin{array}{c}0.152260 \\
(0.389923) \\
\end{array}$ & $\Delta(\mathrm{LFDI})$ & $\begin{array}{c}0.164352 \\
(0.418250) \\
\end{array}$ \\
\hline LDI & $\begin{array}{c}0,587079^{* * *} \\
(0.089375)\end{array}$ & $\Delta(\mathrm{LDI})$ & $\begin{array}{c}0.633704^{* * *} \\
(0.081079)\end{array}$ \\
\hline LGI & $\begin{array}{c}-0.866776^{* * *} \\
(0.185746)\end{array}$ & $\Delta(\mathrm{LGI})$ & $\begin{array}{c}0.935614^{* * *} \\
(0.198706)\end{array}$ \\
\hline LL & $\begin{array}{l}-0.102309 \\
(0.090246) \\
\end{array}$ & $\Delta(\mathrm{LL})$ & $\begin{array}{l}-0.110434 \\
(0.093144) \\
\end{array}$ \\
\hline LH & $\begin{array}{l}1.287786^{* *} \\
(0.399784)\end{array}$ & $\Delta(\mathrm{LH})$ & $\begin{array}{l}1.390060^{* *} \\
(0.465909)\end{array}$ \\
\hline LINFR & $\begin{array}{l}0.855118^{* *} \\
(0.318246)\end{array}$ & $\Delta$ (LINFR) & $\begin{array}{l}0.923030^{*} \\
(0.366182)\end{array}$ \\
\hline LOPEN & $\begin{array}{c}0.149114 \\
(0.076085)\end{array}$ & $\Delta(\mathrm{LOPEN})$ & $\begin{array}{c}0.160957 \\
(0.088023)\end{array}$ \\
\hline LINFL & $\begin{array}{c}-0, .0945^{*} \\
(0.392550) \\
\end{array}$ & $\Delta($ LINFL $)$ & $\begin{array}{l}-0.087031^{*} \\
(0.422892)\end{array}$ \\
\hline LFDIxH & $\begin{array}{l}-0.176932^{* *} \\
(0.670148)\end{array}$ & $\Delta($ LFDIxH $)$ & $\begin{array}{l}-0.918053^{*} \\
(0.778598)\end{array}$ \\
\hline LFDIxINFR & $\begin{array}{l}0.242321^{*} \\
(1.075236) \\
\end{array}$ & $\Delta$ (LFDIxINFR) & $\begin{array}{l}0.261498^{*} \\
(1.096472) \\
\end{array}$ \\
\hline LFDIXOPEN & $\begin{array}{l}-0.632392 \\
(1.427883)\end{array}$ & $\Delta($ LFDIxOPEN $)$ & $\begin{array}{l}-0.682616 \\
(1.554091) \\
\end{array}$ \\
\hline LFDIxINFL & $\begin{array}{c}0.092779 \\
(0.085600)\end{array}$ & $\Delta($ LFDIxINFL $)$ & $\begin{array}{c}0.100147 \\
(0.092040)\end{array}$ \\
\hline C & $\begin{array}{l}4.950402^{*} \\
(3.308872)\end{array}$ & ECM(-1) & $\begin{array}{c}-1.079418^{* * *} \\
(0.111524)\end{array}$ \\
\hline
\end{tabular}

Notes: *Significant at 10\%; **Significant at 5\%; ${ }^{* * * S i g n i f i c a n t ~ a t ~} 1 \%$. The value in () is the standard 
Journal of Business Management and Economic Research (JOBMER), vol.3, issue.6, pp.25-38

With the results of the impact of absorptive factors on the relationship between FDI and economic growth from ARDL model-estimating long-term coefficients (Model 6, table 3) and short-term coefficients (Model 7, table 3). Impact coefficient of LINFR and LH on LG have statistical significance in both cases. Interaction variable between FDI and INFR has positive and statistically significant in both short and long term cases. This shows that infrastructure is really an important factor that promotes the spread of FDI in the localities receiving investment. Because good infrastructure will facilitate economies of scale, reduce trade costs of goods exchange, and therefore an important factor when foreign investors decide to invest in production and business and contribute to economic growth (Zhang, 2001; Hoang et al., 2009; Kotrajaras, 2010; Bao, 2014; Cuong, 2016).

The coefficient of interaction variable between FDI andbH hasbnegativeband statistically significant in both cases. This shows that good quality of labor is an advantage for attracting FDI. However, in this case, the quality of labor in Binh Dinh is low. According to Statistical yearbook of Vietnam 2016, the rate of trained workers in Binh Dinh in 2016 is only 15\%, the lowest compared to 5 provinces of the Central Vietnam key economic region. This is a barrier that limits the contribution of FDI to economic growth. This evidence is similar to some studies such as Borensztein et al., 1998; Anh et al., 2006. Therefore, the places have high human capital which is reflected in the quality of labor. The higher qualification is, the easier and faster the locality will receive technology from FDI. Thereby, human capital plays a role in promoting economic growth through FDI spillover mechanisms.

The impact coefficient of FDI variable on G has not statistically significant in both cases. The estimation results show that no empirical evidence was found for the impact of foreign direct investment on short-term and long-term economic growth. This can be explained in the case of Binh Dinh, FDI capital attracted too little. In addition, implementated capital is lower than registered capital. According to figures of Statistics Office of Binh Dinh Province and General Statistics Office of Vietnam, by the end of 2016, Binh Dinh only attracted 67 projects with a registered capital of 780.3 million USD, accounting for $5.06 \%$ of the registered capital of the Central Vietnam key economic region and $0.27 \%$ Vietnam. Besides, the ratio of implemented capital in Binh Dinh is only 24.3\% compared to the registered capital in the 1997-2016 period.

In summary, research results show that human capital and quality of infrastructure are two important factors that the locality must achieve to benefit from FDI. In other words, the real 
Journal of Business Management and Economic Research (JOBMER), vol.3, issue.6, pp.25-38

motivation for economic growth in Binh Dinh province is the role of FDI with local policy in improving the quality of human capital and infrastructure.

\section{Conclusion}

To find empirical evidence for the existence of absorptive factors that affect to the relationship between FDI and economic growth, this study is conducted with four factors: human capital, infrastructure, macroeconomic stability and trade openness. The research results show that the benefits from FDI will be better in the locality if the locality has good human capital and infrastructure. And FDI promotes economic growth in Binh Dinh province when Binh Dinh has appropriate factors about human capital and infrastructure.

Therefore, the empirical evidences of this research reinforce the view - improving the quality of infrastructure and the quality of labor actually affects absorptive capacity of locality. Based on the research results and the typical context of Binh Dinh province, the author proposes some suggestions to promote the role of local factors in FDI attraction to contribute to economic growth:

(i) Synchronous construction of local infrastructure: In which, Binh Dinh should continue to prioritize investment in upgrading infrastructure of airports, seaports, roads, power grid infrastructure and services. In particular, Binh Dinh needs to handle the environment to actively support projects that promote the highest efficiency in industrial parks.

(ii) Training and developing local human resources to meet the requirements of FDI enterprises in Binh Dinh province and promote the training of high quality human resources. To be detailed, Binh Dinh needs to focus on improving the efficiency of coordination between enterprises, authorities and vocational training institutions in training and recruitment of workers. Besides, Binh Dinh needs to focus on improving management skills at all levels. Especially, the grassroots level about expertise, appraisal and project management capacity to select projects with high efficiency. At the same time, focusing on foreign language training for the workforce to reduce barriers in technology transfer.

\section{References}

Anh, N.T.T., Hong, V.X.N., Thang, T.T., \& Hai, N.M. (2006), Tác động của đầu tư trực tiếp nước ngoài tới tăng trưởng kinh tế ở Việt Nam, Nhà xuất bản Thống kê. [Anh, N.T.T., Hong, V.X.N., 
Journal of Business Management and Economic Research (JOBMER), vol.3, issue.6, pp.25-38

Thang, T.T., \& Hai, N.M. (2006), “ Analysing the impact of foreign direct investment on economic growth in Vietnam, Statistical publisher].

Bao. N.K.Q, (2014), Vai trò của các nhân tố hấp thụ trong mối quan hệ giữa FDI và tăng trưởng kinh tế ở các quốc gia đang phát triển, tạp chí công nghệ ngân hàng, số 102, tháng 9/2014, tr.8-16. [ Bao. N.K.Q, (2014), “The role of absorptive capacity in the relationship FDI and eonomic growth in developing countries", Journal of Banking Technology, 102, pp. 8-16].

Beatrice, F. (2012), Absorptive Capacities and the Impact of FDI on Economic Growth. DIW Berlin 2012, German Institute for Economic Research. ISSN print edition 1433-0210, ISSN electronic, 4535 .

Borensztein, E., De Gregorio, J., and Lee, J. W., (1998), "How does foreign direct investment affect economic growth?", Journal of international Economics, Vol. 45, No. 1, pp. 115-135.

Brown, R.L., Durbin, J., Evans, J. (1975), Techniques for Testing the Constancy of Regression Relations over Time, Journal of the Royal Statistical Society, Vol. 37, pp. 149-163.

Cục thống kê Bình Định, Niên giám thống kê (1997, 2000, 2005, 2010, 2015, 2017), Nhà Xuất Bản Thống Kê. [Binh Dinh Satistical office, Statistical Yearbook (1997, 2000, 2005, 2010, 2015, 2017). Statistical publisher].

Cuong, T. K (2016), Các yếu tố ảnh hưởng đến mối quan hệ của FDI và tăng trưởng kinh tế, Tạp chí phát triển \& hội nhập, số 26(36), tr 10-20. [Cuong, T. K (2016), “ Factors affectting on the relationship of FDI and economic growth" , Journal of Development and Integration.

Dahlman, C., Nelson, R., 1995, Social Absorption Capability, National Innovation Systems and Economic Development. In: Perkins, D.H., Koo, B.H. (Eds.), Social capability and long-term growth. Macmillan Press, Basingstoke.

Dickey, D. A.; Fuller, W. A. (1979), Distribution of the Estimators for Autoregressive Time Series with a Unit Root. Journal of the American Statistical Association. 74 (366), pp. 427-431.

Hoang, T. N, Duysters, G., Patterson, J., and Sander, H. (2009), Foreign Direct Investment Absorptive Capacity Theory. The 7th Globelics International Conference, Dakar, 6 - 8 October 2009. 
Journal of Business Management and Economic Research (JOBMER), vol.3, issue.6, pp.25-38

http://citeseerx.ist.psu.edu/viewdoc/download?doi=10.1.1.308.150\&rep=rep1\&type=pdf. $\quad$ [Accessed May 18, 2018).

Kose, M. Ayhan, Eswar, S. Prasad, and Terrones, E. Terrones, (2006), Financial Integration and Macroeconomic Volatility. IMF Economic Review, 50(1), pp. 119-142.

Kotrajaras, P. (2010), Foreign Direct Investment and Economic Growth: A Comparative Study among East Asian Countries. Applied Economics Journal 17 (2), pp. 12-26.

Nunnenkamp, P. (2004), To what extent can foreign direct investment help achieve international development goals? Blackwell Publishers, Oxford, United Kingdom.

Pesaran, H.M., Shin, Y., and Smith, R. (2001), Bounds testing approaches to the analysis of level relationship. Journal of Applied Econometrics, 16(3), pp. 289-326.

Zhang, K.H (2001), Does foreign direct investment promote economic growth? Evidence from East Asia and Latin America, Contemporary Economic Policy, 19(2), pp. 175-185. 